\title{
Quality Assessment of Stored Harvested Rainwater in Wukari, North-Eastern Nigeria: Impact of Storage Media.
}

\author{
Achadu,* O.J; Ako, F.E and Dalla, C.L \\ Department of Chemistry, Kwararafa University, P.M.B 1019, Wukari, Taraba State, Nigeria.
}

\begin{abstract}
Despite the high level of dependence on rainwater for drinking and domestic uses due to lack of public pipe borne water supplies, little is done for monitoring the quality of stored rainwater in cisterns, tanks and reservoirs receiving rainwater in Wukari, Taraba State, North-Eastern, Nigeria. For this reason, it is very important to evaluate the quality of rainwater collected and stored in different storage media to ascertain their impacts on harvested rainwater quality. In this research study, samples of harvested rainwater were collected from different storage media commonly used (metal tanks, plastic tanks and concrete tanks) from private dwellings and public places. Physico-chemical and microbiological analyses of the samples were carried out using standard methods. The storage material types showed statistically significant differences $(p<0.05)$ in some quality parameters such as $\mathrm{pH}$, Electrical conductivity, Total dissolved solids, acidity, trace and heavy metals.The results of the analyses were compared with water quality guidelines of World Health Organization (W.H.O) to evaluate its suitability for potable and domestic uses. All the stored rainwater samples tested positive for faecal coliform and the counts were above the World Health Organization (W.H.O) stipulation for drinking water. The trace and heavy metals in the water samples were relatively within the World Health Organization (W.H.O) standards except for copper and iron levels in metal tanks. Plastic (PVC) tanks and well constructed concrete tanks are the most suitable storage media as found in this study. The study shows that harvested rainwater may not be suitable for direct drinking, without treatment, but could be used for other domestic purposes.
\end{abstract}

Keywords: Physicochemical, Microbiological, Rainwater harvesting, Storage tanks.

\section{Introduction}

Potable water, a necessary reserve, is in short supply. The global crisis of potable water shortage has sent man on the lookout for new water resources and even more intensively. In light of this, one of the free sources explored to cushion the effects of water shortages is rainwater ${ }^{[1]}$. Rainwater harvesting is necessary in areas having significant rainfall but lacking conventional water supply systems. When rain falls, water is collected either directly or through catchment systems for storage and eventual use. Rainwater is an important source of fresh water especially for those who live in rural areas. One of the primary areas of concern regarding the use of rainwater, for either non-potable or potable applications, is quality. The quality of water collected in a rainwater harvesting system is affected by many factors. which include: the nature of the catchment system and the roof materials, environmental pollution from industries, automobiles and anthropogenic activities, the presence of dirts, debris and birds or rodents dropping on roofs and rainwater catchments ${ }^{[2][3]}$ and the type of storage materials for harvested rainwater. Catchment material, storage material and treatment are three design considerations that can be optimized to maximize rainwater quality. Many studies have also raised the contributions of storage tank materials to the microbiological and physicochemical quality of harvested rainwater. Adeniyi and Olabanji ${ }^{[4]}$ reported that, while roof surfaces are often viewed as a potential source of contamination for rainwater, storage tanks also have their roles in the harvested rainwater quality, especially for rainwater intended for later use and there by stored for long period of time. Hart and White ${ }^{[5]}$ reported that the leaching of metals from metal tanks was found to be significant in a study carried out, but concrete or plastic tanks did not have any notable impact on the concentration of zinc, lead or copper. The leaching of organic compounds is a concern with plastic tanks ${ }^{[6]}$. Sule et al revealed that the quality of water in storage tanks depends on the source and handling of the storage tanks ${ }^{[7]}$. Spinks et al assessed the quality of stored rainwater in southern Australia and reported that chemical contaminants may dissolve during precipitation and leach due to characteristics of the rainwater system components and storage design ${ }^{[8]}$. Forster ${ }^{[9]}$ observed that run-off water quality can be determined by storage conditions. In a similar study Chang et al concludes that storage tanks can be a factor in quality improvement of rainwater ${ }^{[10]}$. The risk of microbiological contamination of rainwater during collection and storage in the home has long been recognized ${ }^{[1]][12]}$. The water storage system can also impact the quality of water ${ }^{[12]}$. Microorganisms found to be carried by birds and animal vectors include, Cryptosporidium, Giardia, Campylobacter and Salmonella spp ${ }^{[13]}$. Each of these microorganisms is known to cause gastroenteritis and other illnesses ${ }^{[13]}$. Depending on the tank material, the water is affected differently. It is very important that users understand the potential hazards and risks of neglect in rainwater 
harvesting. There are wide research gaps with regards to the investigation of many important facts of Rainwater Harvesting (RWH) and rainwater quality changes and treatment mechanisms within storage tanks.

This research is justified due to the significant roles played by storage media in rainwater harvesting in Wukari, its environs and other communities in Nigeria, so as to bridge the gap of intermittent water supply. The study focused on the influence of storage media types on the quality of harvested rainwater. For this, harvested rainwater from different storage media was analysed. The samples collected were checked for different physicochemical and microbiological water quality parameters to determine the sanitary appraisal of stored rainwater, to arrive at conclusions and provide recommendations on quality management of stored rainwater.

\section{Description of study area}

\section{Materials And Methods}

Wukari is the study area and the headquarters of Wukari Local Government Area in Taraba State, Nigeria (Fig. 1). The town lies within the coordinates $7^{\circ} 15^{\prime} \mathrm{N} 9^{\circ} 47^{\prime} \mathrm{E}$ and $7.850^{\circ} \mathrm{N} 9.783^{\circ} \mathrm{E}$. It has an area of $4,308 \mathrm{~km}^{2}$ and a population of 214,546 according to the 2006 National population census of Nigeria. Taraba state is situated in the North-eastern part of Nigeria and lies within the Northern guinea savannah belt. It has an annual rainfall of about $150 \mathrm{~mm}-200 \mathrm{~mm}$ with a mean temperature of $25^{\circ} \mathrm{C}$ and a maximum temperature of $39^{\circ} \mathrm{C}$ ${ }^{[14]}$. Majority of the houses in Wukari are for residential, clinical, religious and educational purposes. Apart from bakeries and sites for local brewery, the town does not have industries or factories. The study area was chosen because of non-availability of public or private water mains in the area, the major source of water for domestic uses are from rain, hand dug wells and boreholes. Unfortunately, the majority of the wells dry up during the dry season when the rain ceases while the borehole water is sold or given restricted access by owners. The community relies extensively on the available rainwater because it is free, accessible in the rainy season and believed to be safe for drinking.

\section{Method of sampling and collection of rain water samples}

The first field work was to identify roof materials and the storage media that are commonly used in Wukari for rainwater harvesting. Sample locations were randomly picked where rainwater harvesting system was already in existence. A random sampling technique was employed in selecting the sampled locations. Three (3) predominant storage tanks (cisterns) were identified, namely: Metal, Plastic (PVC) and Concrete. Private dwellings and public places (hospitals and schools) with the above storage tank types were selected randomly and harvested rainwater samples were collected. Samples of harvested rainwater from various tanks were collected in the months of March and April, 2013. Care was taken to ensure that no accidental contaminations occur during sampling. Sample containers were soaked in acid solution overnight prior to sample collection, followed by proper rinsing with distilled-deionized water and the stored rainwater, before the samples to be analyzed were collected from the storage tanks. The temperature and $\mathrm{pH}$ of the rainwater samples were measured immediately after collection with a Metrohm (USA) hand held Temp/pH meter. Samples for microbial analysis were kept with a sterilized capped bottle to arrest the further growth of bacterial prior to analysis. They were then taking to the laboratory for microbial and physicochemical analyses.

\section{Physico-chemical analysis}

All reagents and chemicals used were of analytical grade and distilled-deionized water was used in all preparations and analyses. The electrical conductivity, total dissolved solids was measured using a JENWAY 3540 Bench combined $\mathrm{pH} /$ conductivity/TDS meter (UK). Turbidity was measured using a potable turbidity meter WAG-WE30210 (UK). Total acidity and chloride measured using titrimetric methods. Sulphate was determined by turbidimetric method and Nitrate was determined by the Brucine method ${ }^{[15]}$. The determination of heavy metals was carried out using the flame atomic absorption spectrophotometer Perkin-Elmer A Analyst 200 (USA) described by APHA's Standard Methods for the Examination of Water and Wastewater $(1998)^{[16]}$.

\section{Microbiological analysis}

Total and faecal coliform bacteria tests are used to assess bacteriological water quality. These tests are used to index hygienic quality because total and faecal coliform are usually associated with faecal contamination and thus, their numbers reflect the degree of pathogenic risks. Also, the tests are relatively easy to perform in comparison with analysis for specific pathogens. Faecal coliform (FC) is the most widely used indicator to determine the possible presence of pathogenic organisms. All bacteriological parameters including total coliform (TC), total bacteria count (TBC) and Confirmatory Faecal coliform test were conducted using the multiple tube fermentation technique (MPN method) using Lauryl tryptose broth for the Presumptive Phase of total and faecal coliforms and Brilliant green lactose bile broth and EC Medium for the Confirmation Phases of Total coliform and Faecal coliform. The water quality analysis was carried out in accordance with the APHA's Standard Methods for the Examination of Water and Wastewater (1998) ${ }^{[16]}$. 


\section{Statistical analysis}

Descriptive statistical analysis was employed for the data obtained. Mean, range, standard deviation and coefficient of variation (CV) were determined. The parameters were tested for any significant difference amongst the storage media types.

\section{Physico-chemical parameters results}

\section{Results}

The physicochemical and microbiological rainwater quality results are presented in Tables 2 and 3 respectively. The temperature recorded was in the range of $26.5-27^{\circ} \mathrm{C}$ for metal tanks, plastic tanks recorded an average of $27^{\circ} \mathrm{C}$ in all samples and the concrete tanks ranged from $23-25^{\circ} \mathrm{C}$. For $\mathrm{pH}$, electrical conductivity and total dissolved solids (TDS), metal tanks recorded values within the following ranges; 5.1-6.2, 20-62 $\mu \mathrm{S} / \mathrm{cm}$ and $10.5-31.5 \mathrm{mg} / \mathrm{L}$ respectively. Plastic (PVC) tanks ranged from 5.2-6.2, 30-40 $\mu \mathrm{S} / \mathrm{cm}$ and $15.0-20.2 \mathrm{mg} / \mathrm{L}$. The values in concrete tanks were found to be between $7.2-8.5,32-64 \mu \mathrm{S} / \mathrm{cm}$ and $12.5-33.5 \mathrm{mg} / \mathrm{L}$ for $\mathrm{pH}$, electrical conductivity and TDS respectively. Turbidity (NTU) ranged from 1.0-1.5, 1.0-1.2 and 1.0-1.5 in metal, plastic (PVC) and concrete tanks respectively. Total acidity values were within the following ranges $1.5-8.5 \mathrm{mg} / \mathrm{L}$ in metal tanks. Plastic (PVC) tanks recorded (in $\mathrm{mg} / \mathrm{L}$ ) 2.1-6.0 respectively. In concrete tanks, total acidity values were found to be within the range of $1.2-2.3 \mathrm{mg} / \mathrm{L}$ respectively. Metal tanks gave the range for nitrate, sulphate and chloride value as $<0.01-3.1,1.8-5.8$ and $<0.01-0.90 \mathrm{mg} / \mathrm{L}$ respectively. Plastic (PVC) tanks ranged from $0.2-2.1,2.01-5.3$ and $<0.01-1.20 \mathrm{mg} / \mathrm{L}$ for nitrate, sulphate and chloride.

The mean concentrations of trace and heavy metal detection in the samples analysed is shown in Table 1. Calcium has mean values of $3.86 \pm 1.6,3.93 \pm 0.7$ and $6.14 \pm 2.4 \mathrm{mg} / \mathrm{L}$ in metal, plastic (PVC) and concrete tanks respectively. Magnesium mean values found in metal, plastic (PVC) and concrete tanks were $2.04 \pm 1.6$, $1.36 \pm 0.7$ and $2.22 \pm 1.2 \mathrm{mg} / \mathrm{L}$ respectively. Al was only detected in metal tank samples with a mean concentration of $0.02 \pm 0.01 \mathrm{mg} / \mathrm{L}$. Iron was recorded in all samples analysed from the different storage media, with mean values of $1.71 \pm 0.4,0.90 \pm 0.3$ and $0.91 \pm 0.2$ for metal, plastic and concrete tanks respectively. $\mathrm{Cu}$ and $\mathrm{Zn}$ detected in metal tanks had mean concentrations of $1.11 \pm 0.4$ and $0.99 \pm 0.5 \mathrm{mg} / \mathrm{L}$. Plastic (PVC) tanks showed mean values of $0.75 \pm 0.3$ and $0.52 \pm 0.2 \mathrm{mg} / \mathrm{L}$ respectively. Concrete tanks had mean concentrations of $0.39 \pm 0.3$ and $0.77 \pm 0.4 \mathrm{mg} / \mathrm{L}$ for $\mathrm{Cu}$ and $\mathrm{Zn}$ respectively. $\mathrm{Pb}$ and $\mathrm{Cr}$ were not detected in all samples analyzed.

\section{Microbiological analysis results}

The microbiological analysis results (Table 3) show that all stored rainwater samples tested had coliforms detected. The confirmatory coliform test was positive in all samples. Of all three storage media tanks, rainwater samples in concrete tanks recorded the lowest mean total bacteria counts (TBC) of $860 \pm 20.5$ MPN/100mL (Table 3), followed by the metal tanks having mean TBC value of $1060 \pm 50.5 \mathrm{MPN} / 100 \mathrm{~mL}$. Plastic (PVC) tanks recorded the highest total bacteria (TBC) and total coliform (TC) (Table 3).

\section{Physico-chemical}

\section{Discussion}

The storage material types showed statistically significant differences $(\mathrm{p}<0.05)$ in some quality parameters such as $\mathrm{pH}$, Electrical conductivity, Total dissolved solids, acidity, trace and heavy metals determined in the stored rainwater samples. The difference in the values of the parameters of different storage media types shows the impact of the media on the stored rainwater. Metal and concrete tanks showed the most differences in the parameters owing to the release of the component materials of the tanks. $\mathrm{pH}$ was found to be lowest in metal tanks with a mean value of $5.53 \pm 0.4$ and coefficient of variation (CV) of $7.23 \%$ which show no significant variation in all metal tanks sampled (Table 2). Concrete tanks were found to have a mean value and $\mathrm{CV}$ of $7.8 \pm 1.7$ and $21.7 \%$ respectively (Table 2 ). The high $\mathrm{pH}$ of stored rainwater in the concrete tanks can be attributed to the neutralizing input of the concrete tanks alkaline components. The $\mathrm{pH}$ of plastic and concrete tanks were within the permissible limits of the W.H.O standards for potable water, but that of the metal tanks was found below (not within the range) the acceptable limits.

Electrical conductivity, total dissolved solids (TDS) and acidity were found to vary significantly $(\mathrm{p}<0.05)$ between metal and concrete tanks. Plastic and concrete tanks were found to vary significantly in electrical conductivity and total dissolved solids. Conductivity was highest in metal tanks (Fig. 2) which can be explained from the low $\mathrm{pH}$ and the leaching of metal tanks components into the stored rainwater. Turbidity shows no significant difference $(p<0.05)$ in the storage media types. This can be attributed to the fact that suspended solids tend to settle at the bottom of the tanks at long storage periods. Low values of turbidity within the range of 1.0-1.5 NTU were determined in all stored rainwater sampled. This conforms to the acceptable standards and guidelines for potable water quality of 5.0 NTU of W.H.O. Nitrates, sulphates and chlorides results (Fig. 3) in samples from all storage media types show no significant difference $(p>0.05)$ which indicated 
no contribution to the parameters from the storage material types and the slight differences recorded in values might be due to the different sample locations.

\section{Trace and heavy metals}

The levels of calcium and magnesium varied significantly in the storage material types. The highest values were found in the concrete tanks, this expectedly is due to the calcium carbonate as the major constituent of cement used in concrete tanks. Calcium and magnesium however showed no significant difference in metal and plastic tanks. Zinc, iron and copper levels were found to be highest in metal tanks (Fig. 4). The mean values of copper and iron found in metal tanks exceeded the recommended limits of W.H.O (Table 1). This can be attributed to the low $\mathrm{pH}$ of the stored rainwater in metal tanks which increases the potentials for the leaching of metals from the metal tank. Another important factor in the leaching of the metals into the stored water could be attributed to the long storage time of the slightly acidic rainwater in the tanks. The difference between the concentration of zinc, copper and iron were found to be significant $(\mathrm{p}<0.05)$ between metal and plastic tanks, also between metal and concrete tanks. In plastic and concrete tanks the levels of zinc, iron and copper showed no significant difference $(\mathrm{p}<0.05)$. Metal tanks exceeded the W.H.O allowable limits for iron and copper. Concrete and plastic tanks were within W.H.O acceptable limits for zinc and copper, except for iron (Table 1).

Comparing these results with those presented in the literature, Sazakli et al ${ }^{[17]}$ reported a similar range of $\mathrm{pH}$ values, 7.6-8.8, for rainwater stored in concrete cisterns in Greece. In a study of 125 households in New Zealand with rain water harvesting $(\mathrm{RWH})$ systems, Simmons et al also found a statistically significant difference between concrete and non-concrete storage tanks (plastic, wood, fibreglass or galvanized iron) which had median $\mathrm{pH}$ values of 7.5 and 5.9 , respectively ${ }^{[18]}$. Scott and Waller attributed the increased $\mathrm{pH}$ in concrete tanks to the leaching of calcium carbonate from the concrete storage tank walls ${ }^{[19]}$. The results of the mean values (Table 2) of conductivity, TDS, turbidity, acidity are well below the maximum contaminant levels established by W.H.O standards. Since the stored water is rainwater and not groundwater, these parameters are not expected to be high. Ziadat studied stored rainwater (cistern) quality in Al-Karak Province, Jordan ${ }^{[20]}$ and reported that none of the chemical parameters (calcium, magnesium, chloride, sodium, potassium, bicarbonate, sulphate, nitrate, $\mathrm{pH}$ and electrical conductivity) tested from storage tanks exceeded the W.H.O and Jordanian standards. Similar results (within acceptable limits for water quality) were also obtained for trace and heavy metals determined in stored rainwater from different storage tanks in this study, except for iron and copper in metal tanks. The metals results were consistent with the findings of Despins et al which reported that trace and heavy metals were detected in very low concentrations in cisterns stored rainwater in Canada ${ }^{[21]}$, except for calcium with concentration between 8-12 mg/L. Environmental factors and anthropogenic activities are major factors in rainwater quality variations in different locations. Despins et al observed that leaching of zinc was significantly different in metal tanks than from concrete and plastic tanks. Concrete and plastic tanks have been reported to have no notable impact on the concentrations of heavy metals in stored rainwater ${ }^{[22]}$. However, the leaching of organic and other hazardous compounds has been reported as a concern in plastic or PVC tanks especially those that have been previously used for storing those organic compounds and now used for water storage ${ }^{[23]}$.

\section{Microbiological}

From the results (Table 3) the concrete tanks were found to have the lowest levels of microbial contamination in the stored rainwater samples. The most contaminated were the plastic tanks as the level of microbial contamination varied significantly $(\mathrm{p}<0.05)$ in the storage material types.

The difference in the microbial levels (Fig. 5) has been attributed to the $\mathrm{pH}$ variations and temperature of the stored rainwater in the storage media ${ }^{[24]}$. Studies have found some correlations between $\mathrm{pH}$ and growth of coliforms in rainwater tanks ${ }^{[25]}$. The total coliform was lowest in concrete tanks which have the highest mean $\mathrm{pH}$ value in this study. This trend was however, not observed in metal tanks with $\mathrm{pH}$ values lower than that of plastic tanks and lowest in all storage media. This difference has been reported in a study where the effect of temperature was found to have a significant difference in the levels of micro-organisms in stored rainwater in different storage media ${ }^{[26]}$. It has been observed that metal tanks maintain higher temperature than the plastic tanks and hence the varying micro-organisms level. The same trend is however not followed when the microbial levels of stored rainwater in metal tanks and concrete tanks were compared, which suggests that the effect of $\mathrm{pH}$ on microbial level impacted more than the temperature for which no significant difference $(p<0.05)$ was observed.

The microbiological results show that all the stored rainwater samples did not pass the microbiological examinations (Table 3). The reports in the literature are similar to that obtained in this study. Analysis showed that the selected tanks' stored rainwater was polluted and unsuitable for drinking. Total coliform of rainwater in these storage media is an indication of faecal contamination. This shows that various catchment systems and roofs have waste matters being transported into collection/storage tanks. The presence of faecal coliform in 
water indicates that faecal pollution had occurred. This poses great danger to human health. Contamination of water by human and animal waste deposits constitutes the most common mechanism for transmission of microorganisms to humans ${ }^{[27]}$. These pathogenic organisms are responsible for the infection of the intestinal tracts and the diseases caused include; diarrhoea, cholera, bacillary dysentery, typhoid, hepatitis and so on. The incidence of water borne diseases can therefore be attributed to untreated or poorly treated stored rainwater that contains pathogens ${ }^{[28]}$.

\section{Figures And Tables}

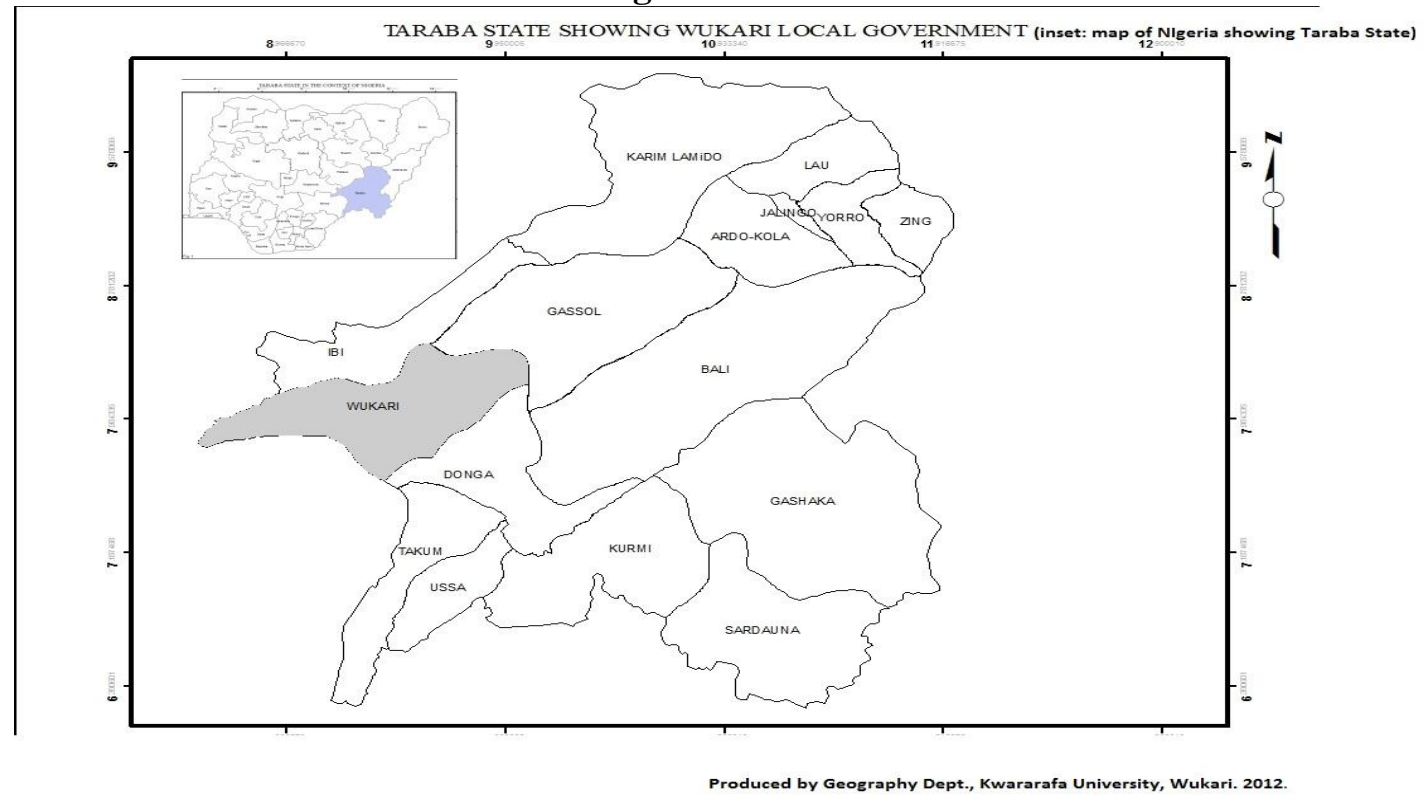

Figure 1. Map of Taraba state (Nigeria) showing Wukari.

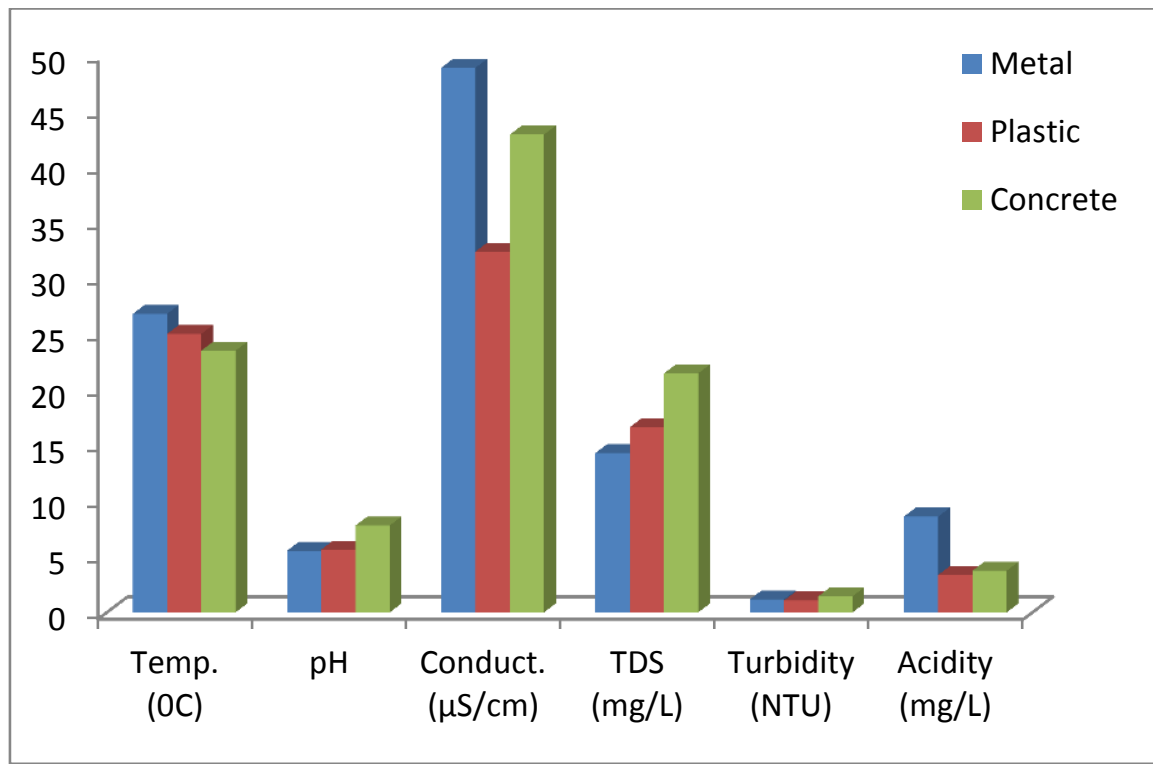

Figure 2. Physico-chemical parameters of stored rainwater samples in different storage media. 


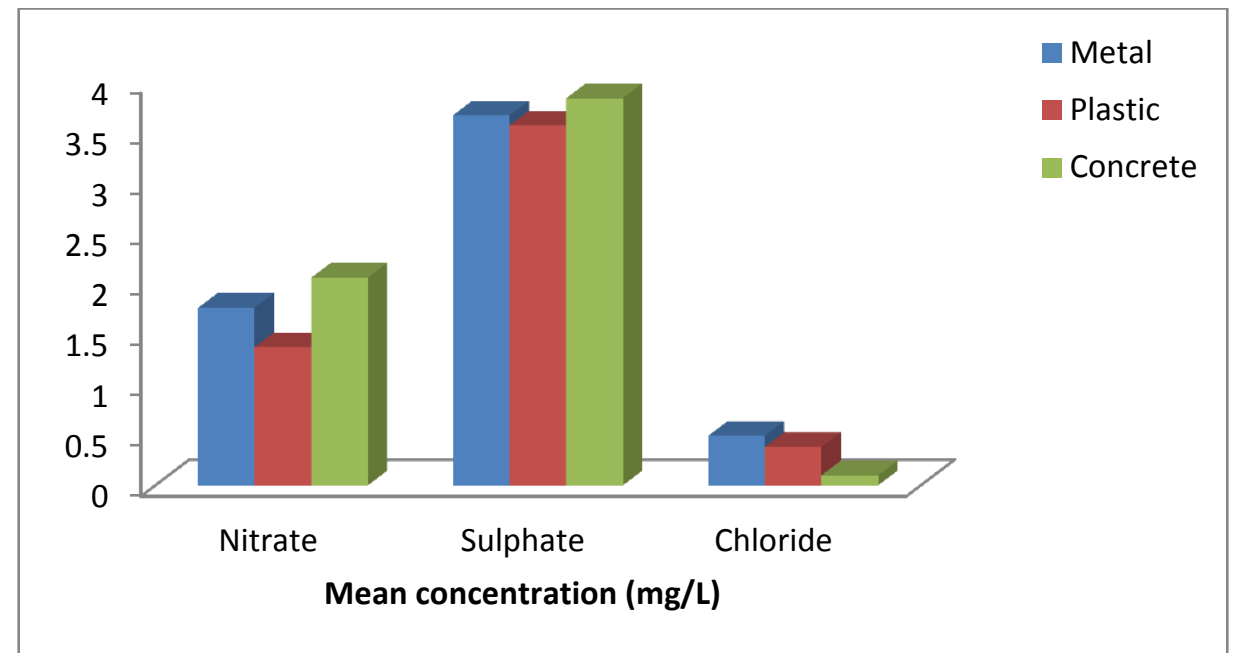

Figure 3. Nitrate, sulphate and chloride levels of stored rainwater samples in different storage media.

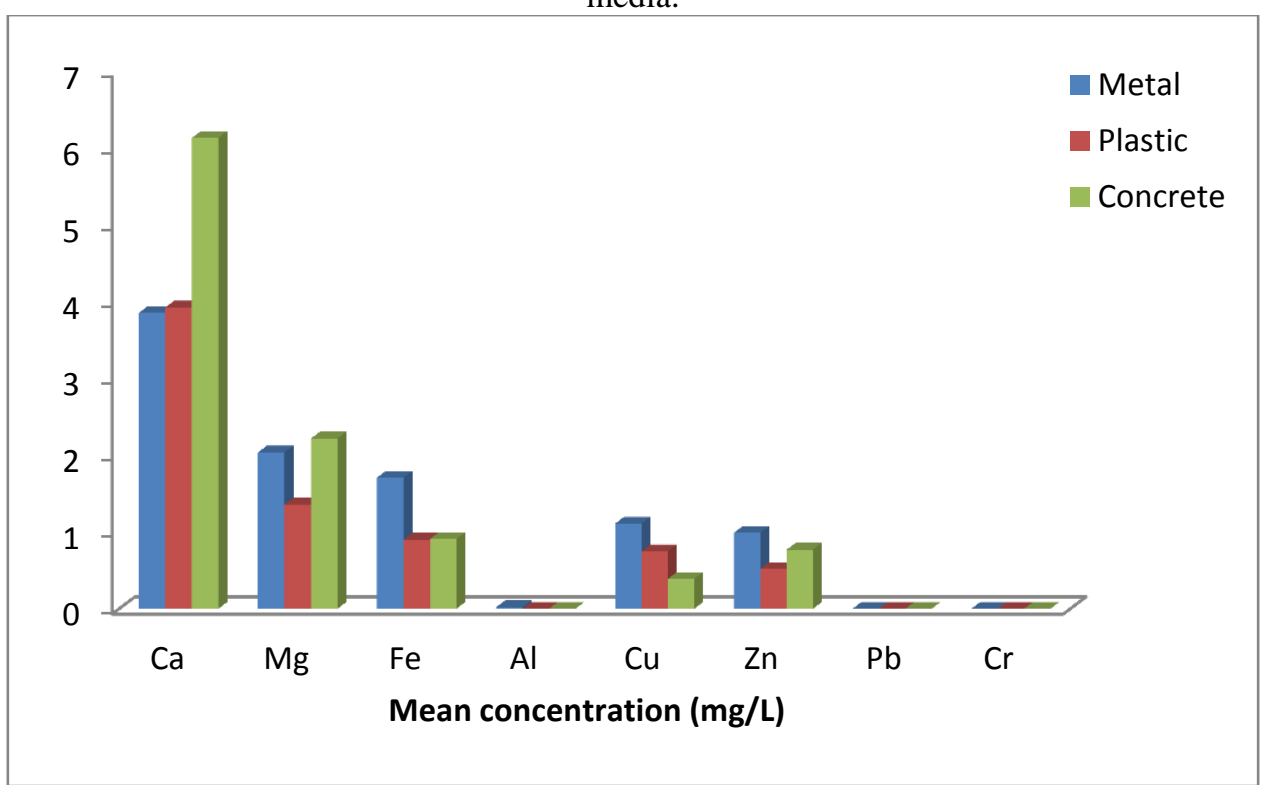

Figure 4. Trace and heavy f metals levels of stored rainwater samples in different storage media.

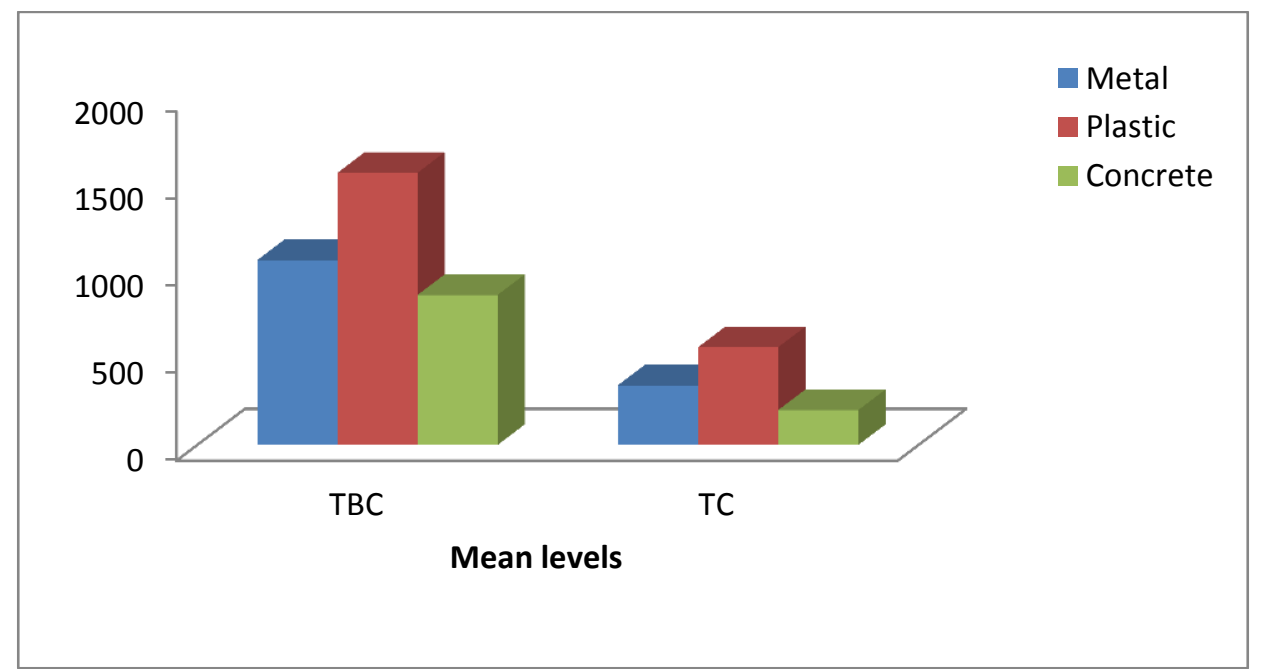

Figure 5. Microbiological parameters of stored rainwater samples in different storage media. 
Table 1. Mean $\pm \mathrm{SD} *$ trace and heavy metals of stored rainwater samples in different media.

\begin{tabular}{|c|c|c|c|c|c|c|c|}
\hline Parameter & Metal & & Plastic & & Concrete & & WHO \\
\hline & Mean \pm SD & $\mathrm{CV}(\%)$ & Mean \pm SD & $\mathrm{CV}(\%)$ & Mean \pm SD & $\mathrm{CV}(\%)$ & \\
\hline $\mathrm{Ca}(\mathrm{mg} / \mathrm{L})$ & $3.86 \pm 1.6$ & 41.45 & $3.93 \pm 0.7$ & 17.8 & $6.14 \pm 2.4$ & 39.08 & 75 \\
\hline $\mathrm{Mg}(\mathrm{mg} / \mathrm{L})$ & $2.04 \pm 1.6$ & 78.43 & $1.36 \pm 0.7$ & 51.47 & $2.22 \pm 1.2$ & 54.05 & 50 \\
\hline $\mathrm{Fe}(\mathrm{mg} / \mathrm{L})$ & $1.71 \pm 0.4$ & 23.39 & $0.90 \pm 0.3$ & 33.33 & $0.91 \pm 0.2$ & 21.97 & 0.3 \\
\hline $\mathrm{Al}(\mathrm{mg} / \mathrm{L})$ & $0.02 \pm 0.01$ & 50 & ND & - & ND & - & - \\
\hline $\mathrm{Cu}(\mathrm{mg} / \mathrm{L})$ & $1.11 \pm 0.4$ & 36.04 & $0.75 \pm 0.3$ & 40 & $0.39 \pm 0.1$ & 25.64 & 1.0 \\
\hline $\mathrm{Zn}(\mathrm{mg} / \mathrm{L})$ & $0.99 \pm 0.5$ & 50.5 & $0.52 \pm 0.2$ & 38.46 & $0.77 \pm 0.4$ & 51.95 & 5.0 \\
\hline$\overline{P b}(\mathrm{mg} / \mathrm{L})$ & ND & - & ND & 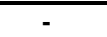 & ND & - & 0.05 \\
\hline $\mathrm{Cr}(\mathrm{mg} / \mathrm{L})$ & ND & - & ND & - & ND & - & 0.05 \\
\hline
\end{tabular}

*Mean result $(\mathrm{n}=10)$ for each storage medium.

Table 2 Mean $\pm \mathrm{SD}^{*}$ of physicochemical parameters result of stored rainwater samples.

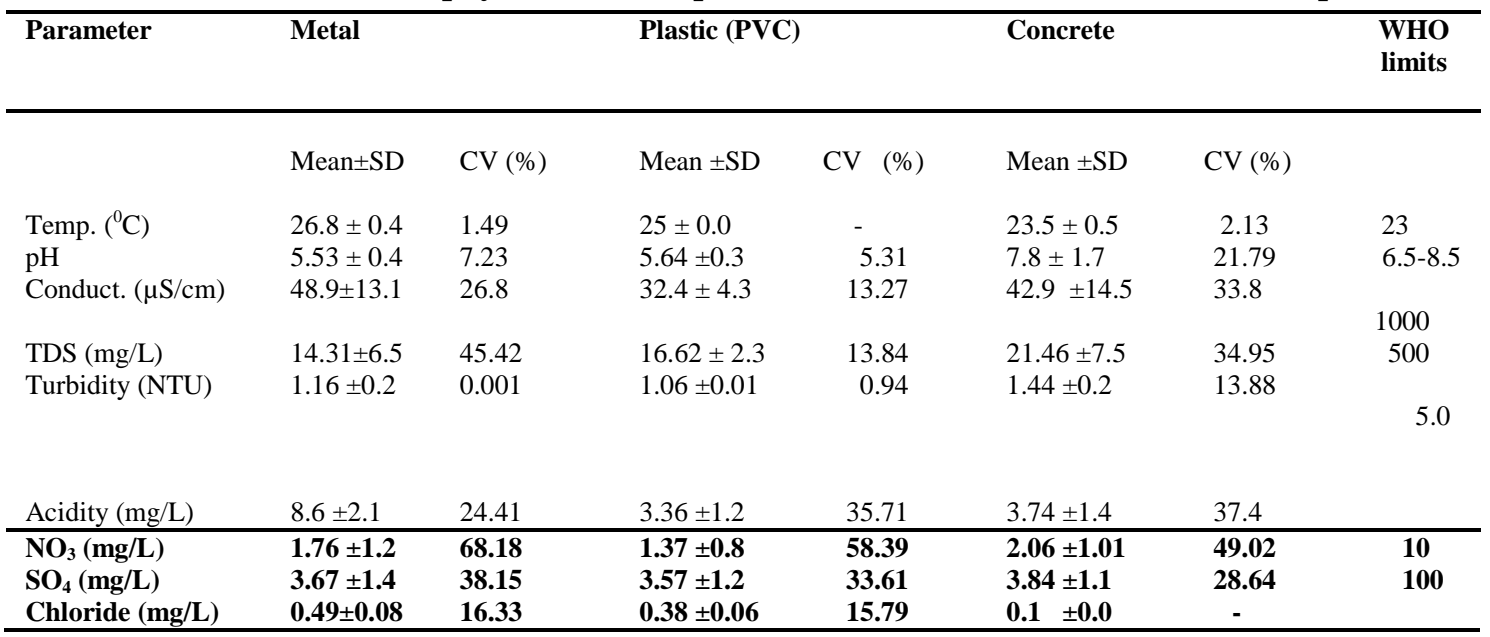

$*$ Mean result $(\mathrm{n}=10)$ for each storage medium.

Table 3 Mean \pm SD* of microbiological parameters of stored rainwater samples in different media

\begin{tabular}{|c|c|c|c|c|}
\hline Parameter & Metal & Plastic (PVC) & Concrete & $\begin{array}{l}\text { WHO } \\
\text { limits }\end{array}$ \\
\hline & Mean \pm SD & Mean \pm SD & Mean \pm SD & \\
\hline Total Bacteria Count MPN/100ml & $1060 \pm 50.5$ & $1560 \pm 36.0$ & $860 \pm 20.5$ & 0 \\
\hline Total Coliform (CFU/100ml) & $342 \pm 23.5$ & $560 \pm 12.8$ & $200 \pm 16.9$ & 0 \\
\hline Confirmatory faecal coliform test & + ve & + ve & + ve & -ve \\
\hline
\end{tabular}

*Mean result $(\mathrm{n}=10)$ for each storage medium.

\section{Conclusion}

This study focused on the influence of different storage tank types on the quality of harvested rainwater. The physicochemical properties of rainwater were most influenced by the different types of storage tanks and their component materials. Statistically significant differences were also observed in some physicochemical quality parameters between metal and concrete tanks. The microbiological quality of the harvested stored rainwater appears to depend, in part, on the handling and storage patterns by users of the rainwater. There were however, significantly different influence observed for the different types of storage media on the microbial quality of the stored rainwater and the levels of the microorganisms differed significantly $(p<0.05)$ amongst storage media. The results of this study are in keeping with a number of other national and international studies that show the overall poor water quality (microbiological contamination) of harvested rainwater, as the microbiological quality of the stored rainwater sample were below valid standards and allowable limits for drinking water quality. Whereas, the physicochemical quality parameters conform to W.H.O water quality guidelines, except for the levels of copper and iron in metal tanks that exceeded recommended limits of W.H.O. In order to have better quality of harvested rainwater in storage, the catchment roofs and run-offs must be properly washes before the start of rainy season, Plastic (PVC) tanks and well constructed concrete tanks are the 
most suitable as found in this study. Stored water should be treated by adding some disinfecting agents such as chlorine which might help in reducing the risk of microbiological contaminations.

Expectedly, the surrounding environment and the storage tanks owners' low awareness of preventing rainwater contamination are among key factors that contribute to harvested rainwater contamination. Rainwater could be used for both potable and non-potable purposes. It must be highlighted though that rainwater should go through proper treatments in order to be used for potable purposes. Finally, public awareness has an important role in collected rain water management. Education, training, and financial supports are needed to encourage people to consider the importance and quality of collected water.

\section{Acknowledgement}

The authors wish to acknowledge the contributions of Mr Mejida, S. (MNIST) (Central Research Laboratory of the University of Lagos, Akoka, Lagos) for the laboratory analyses of this research study.

\section{References}

[1]. J.E. Gould, Is rainwater safe to drink? A review of recent findings. Proceedings: $9^{\text {th }}$ International Rainwater Catchment Systems Conference, Petrolina, Brazil. (1999)

[2]. J. Forster, The influence of location and season on the concentrations of macro-ions and organic trace pollutants in roof runoff. Water Sci. Technol. 38(10) (1998), 83-90.

[3]. R. Taylor., D. Sloan., T. Cooper., B. Morton and I. Hunter, A waterborne outbreak of Salmonella Saintpaul. Commun. Dis. Intell. 24(11) (2000), 336-340.

[4]. I.F. Adeniyi, and I.O. Olabanji, The physico-chemical and bacteriological quality of rainwater collected over different roofing materials in Ile-Ife, South-western Nigeria. Chemistry and Ecology, 21(3) (2005):149-166.

[5]. C. Hart, and D. White, Water quality and construction materials in rainwater catchments across Alaska. J. Environ. Eng. Sci. 5(1) (2006), 19-25

[6]. EPA (2002). Permeation and Leaching. Distribution System Issue Paper. Available at: www.epa.gov/safewater/disinfection/tcr/pdfs/ whitepaper_tcr_permation-leaching.pdf.

[7]. T.O. Sule., A. Agbabiaka, and V. Akomolafe, Bacteriological Quality of Water Stored Exteriorly in Storage Tanks. Res. J. Environ. Sci. (2011) pp3-5.

[8]. A. Spinks, B. Berghout, R. Dunstan, P. Coombes and G. Kuczera. Tank sludge as a sink for bacterial and heavy metal contaminants and its capacity for settlement, re-suspension and flocculation enhancement. In: Proceedings of the 12th International Rainwater Catchment Systems Association Conference, November, New Delhi, India. (2005).

[9]. J. Forster, Variability of roof runoff quality. Water Sci. Technol. 39(5) (1999), 137-144.

[10]. M. Chang, W. McBroom and R. S. Beasley, Roofing as a source of non point water pollution. Journal of Environmental Management. Vol.73. (2004). 307-315.

[11]. D. J. Lye, Health risks associated with consumption of untreated water from household roof catchment systems. J. Am. Water Resour. Assoc. 38(5) (2002), 1301-1306.

[12]. F. Thomas, C. Bastable and A. Bastable, Faecal contamination of drinking water during collection and household storage: the need to extend protection to the point of use. Journal of Water and Health 1(3) (2003), 109-115.

[13]. C. Gerba and J. Smith, Sources of pathogenic microorganisms and their fate during land application of wastes. Journal of Environmental Quality. 34 (2005), 42-48.

[14]. Taraba State Government Diary (2010).

[15]. C.M.A. Ademoroti, Standard Methods for water and Effluent Analysis. Foludex Press Ltd, Ibadan, Nigeria. (1996). p 420.

[16]. APHA, Standard Methods for the Examination of Water and Wastewater, $20^{\text {th }}$ ed. Washington, D.C: American Public Health Ass. WPCF and AWWA. (1998).

[17]. E. Sazakli, A. Alexopoulos and M. Leotsinidis, Rainwater harvesting, quality assessment and utilization in Kefalonia Island, Greece. Water Res. 41(9) (2007), 2039-2047.

[18]. G. Simmons, V. Hope, G. Lewis, J. Whitmore and W. Gao, Contamination of potable roof-collected rainwater in Auckland, New Zealand. Water Research, 35(6) (2001). 1518-1524.

[19]. R. Scott, and D. Waller, Water quality analysis of a rainwater cistern system in Nova Scotia, Canada. In: Proceedings of the 3rd International Rainwater Collection System Association Conference. Khon Kaen, Thailand. (1987).

[20]. A. Ziadat, Impact of storage tanks on drinking water quality in Al-Karak Province - Jordan. Journal of Applied Sciences 5(4) (2005), 634-638.

[21]. C. Despins, K. Farahbakhsh and C. Leidl, Assessment of rainwater quality from rainwater harvesting systems in Ontario, Canada. Journal of Water Supply: Research and Technology-AQUA 58 (2) (2009), Pp 117 -134.

[22]. R. Jamal, A. Kamel, A. Adnan and A. Rida, Quality Assessment of Harvested Rainwater for Domestic Uses. Jordan Journal of Earth and Environmental Sciences. Vol.2. No 1. (2009). Pp $26-31$.

[23]. N.S.F (National Sanitation Foundation), Drinking Water System Components-Health Effects. NSF International, Ann Arbor, Michigan. NSF/ANSI 61-2007.

[24]. K. Zhu, L. Zhang, W. Hart, M. Liu, and H. Chen, Quality issues in harvested rainwater in arid and semi-arid Loess Plateau of northern China. J. Arid Environ. 57(4) (2004), 487-505.

[25]. R. Bannister, J. Westwood, and A. McNeil, Investigation of micro-biological and chemical water quality in rainwater tanks in Victoria, Melbourne. Water ECO science report no.139/97-Department of Natural Resources and Environment (1997). 56.

[26]. M. T. Amin, and M.Y. Han, Microbial quality variation within a rainwater storage tank and the effects of first flush in Rainwater Harvesting (RWH) System. Australian Journal of Basis and Applied Sciences, 5(9) (2011a). 1804-1813.

[27]. P. Namrata and H. Han, Rainwater Harvesting and Health Aspects - Working on W.H.O guidance. NGO forum, Nepal. The paper output of collaborative programme on water quality management organized by the World Health Organization. (2005). Pp65.

[28]. World Health Organization, W.H.O. Guidelines for Drinking Water Quality. $3^{\text {rd }}$ Edition, Vol. 1. Recommendation. World Health Organization, Geneva, Switzerland. (2004).18. 